\title{
Atmospheric Electrical Properties of Snow Clouds with Precipitation
}

\author{
By Katsuhiro Kikuchi \\ Department of Geophysics, Hokkaido University, Sapporo \\ (Manuscript received 6 May 1975)
}

\begin{abstract}
Simultaneous observations of the surface electric field, shape and charge on snow crystals and melted diameters of the crystals were carried out at the seashore of Ishikari near Sapporo where snow clouds of falling snow accompanied by northwesterly winds were observed during the winter monsoon season.

From the observational results, it was confirmed that in general dendritic crystals were negatively charged under a positive electric field and relatively large dendritic snowflakes, densely rimed crystals and soft hail were positively charged under a negative electric field. Furthermore, it was found that when positive snow crystals fell, the mode value of the size distribution of melted diameter at that moment shifted to smaller values as compared with that when negative snow crystals fell alone. Therefore, it was considered that snowflakes and densely rimed crystals were positively charged when small fragments were torn off from fragile flakes and crystals during their descent and at such times small fragments acquired negative charges. Moreover, suspended small fragments acquired negative charges when they collided with the falling flakes and crystals. As a result, the main crystals acquired positive charges as a matter of course.
\end{abstract}

\section{Introduction}

A few observations of electric charges on snow crystals comparable to that on rain drops have been carried out till the present as summarized in the publications by Chalmers (1967) and Mason (1971 a). Moreover the results reported were different. The divergence between the different results was probably due to differences in the conditions under which the observations were made. For instance, Nakaya and Terada (1934) showed a predominance of negatively charged flakes in dry snow, but when the flakes had water drops attached, they were often positively charged. Simpson (1942) and Chalmers and Little (1947) showed that quietly falling snow was usually negatively charged, while snow under turbulent conditions was more often positive. But, no reports described the shapes of the snow crystals. However, it has been generally accepted that the polarity of the electrical charges on snow crystals is negative. Recently, the author carried out some observations of electrical charges on the natural falling snow crystals and blizzard snow particles, especially on the shapes of snow crystals and electric field strength when the author was a member of the winter-over party of the 9th Japanese Antarctic Research Expedition at Syowa Station Antarctica throughout a whole year from February 1968 to January 1969 (Kikuchi, 1970, 1973). As a result, the shapes of negatively charged snow crystals are restricted to "Dendrite" and "Plate". And "Column", "Bullet" and "Side Planes" are charged positively. These statistical results are important because of the following facts, namely, the observations were carried out in the Antarctica, they were natural snowfalls, sample numbers measured were numerous and there were no wave patterns of electric field during these snowfalls.

On the other hand, generally in the sub-tropical regions the precipitations from convective clouds independent of rain or snow give some disturbances such as wave patterns to the atmospheric electric field. Under such conditions, it is known that there are a "mirror image relation" between the polarity of the electrical charges (or current) on precipitation particles and the polarity of the electric field (Simpson, 1949; Sivaramakrishnan, 1957; Magono and Orikasa, 1960, 1961, 1966 a, 
b; Orikasa, 1962; Chalmers, 1965; Owolabi, 1970). Furthermore, there are some observational results by Orikasa (1962) and Magono and Orikasa (1966 a) at Sapporo in which the electrical polarity of soft hail and relatively large snowflakes seemed to be positive. The same results were confirmed by the author at the seashore of Ishikari near Sapporo where snow clouds with falling snow accompanied by northwesterly winds were observed during the winter monsoon season. This paper describes the atmospheric electrical properties of snow clouds and the charging mechanisms of snowflakes and soft hail based on the simultaneous observations of atmospheric electric field, shape and charge on snow crystal and melted diameter of the crystal.

\section{Observation site and equipments}

The seashore of Ishikari approximately $20 \mathrm{~km}$ to the north of Sapporo was selected as the observation site (Fig. 1). Because a few observations carried out hitherto were on the Hokkaido University campus in Sapporo above which snow clouds sometimes were in the dissipating stage. According to Takahashi's warm rain observation (1972 a, b) at Hilo, Hawaii, the electrical polarity of precipitation elements changed over the ocean near the seashore and over the land. This means that the polarity is changeable with the stage of clouds, namely, the developing and dissipating stages. In general, snow clouds invading over the Bay of Ishikari on the Sea of Japan provides some snowfall which at times causes violent snow storms on the Ishikari Plain. Especially, some snowfalls and snow storms accompanied by the northwesterly wind in the winter monsoon season give densely rimed crystals or soft hail, and snowflakes or single crystals periodically along the seashore from developing convective clouds (Magono et al. 1966). Therefore, the seashore of Ishikari is a good location for field observations of electrical charges on snow particles and electric field of snow clouds.

The observation of the shapes of snow crystals was done by a microscopic photography and the replica solution method. The melted diameters of the snow particles were recorded on filter papers. The charges on snow particles were measured by causing the current flow through a high resistance for each particle. The measuring limit of the electrometer was $2 \times 10^{-4}$ esu.

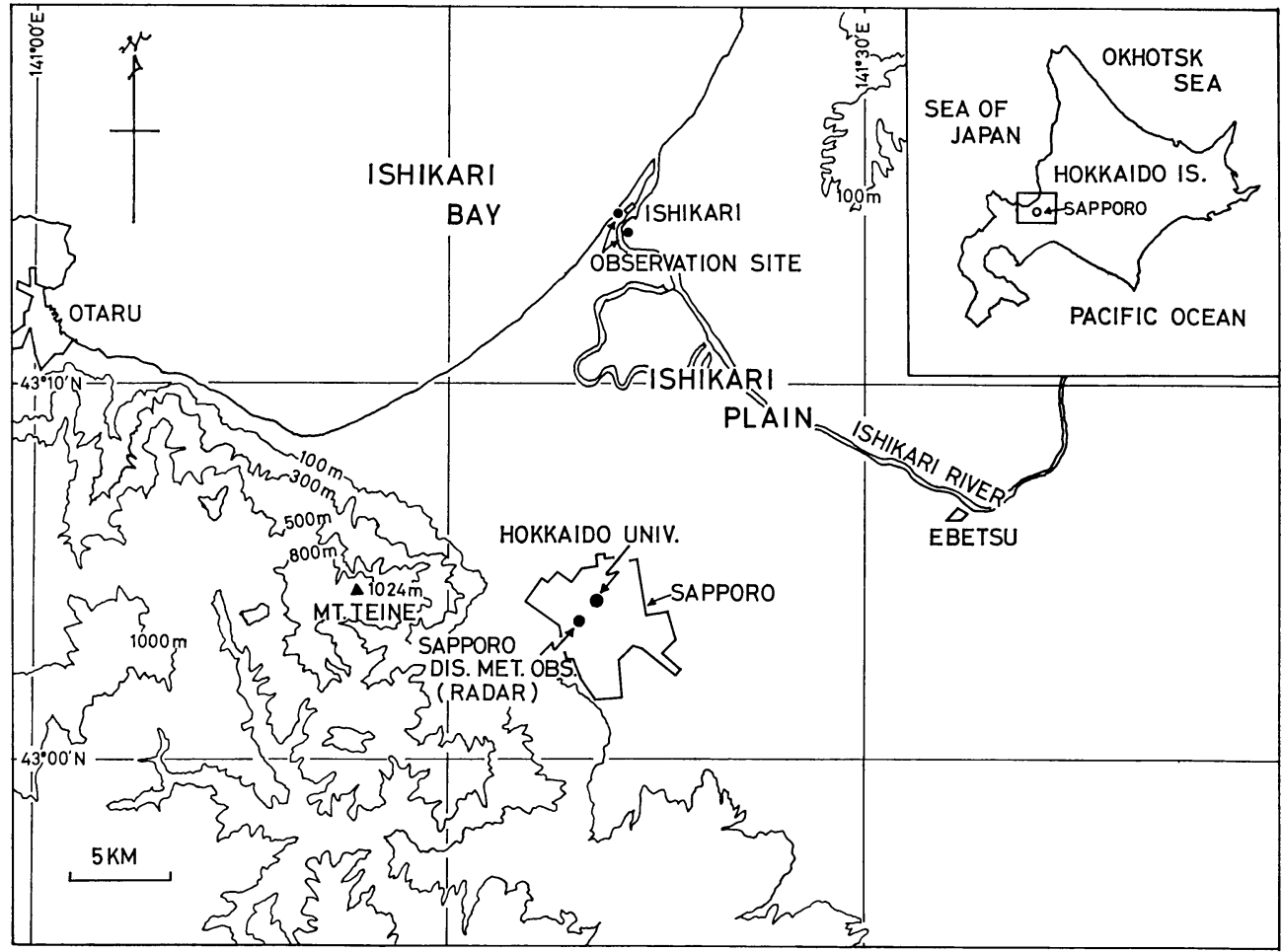

Fig. 1 Map around the observation area. 
At the same time a "field mill" type of electrometer was used for the observation of electric field strength. The recorder of the field mill was operated at 60 to $300 \mathrm{~mm} \cdot \mathrm{hr}^{-1}$ of chart speed in all weather. On the other hand, the recorder of the charge meter was run at 120 $\mathrm{mm} \cdot \mathrm{min}^{-1}$ of chart speed during precipitation time alone. Wind direction and velocity were measured by an aerovane type anemometer during the observation period. The microscopic photography and replica solution method and filter paper method were carried out at approximately 5 to 10 minutes intervals, respectively.

\section{Observational results.}

Fig. 2 shows a typical example of snow clouds invading from over the bay to the Ishikari Plain under the condition of northwesterly wind during the monsoon period. As seen in this figure, the cloud form belongs to "Cumulus Congestus". The top of the clouds, however, is not so high

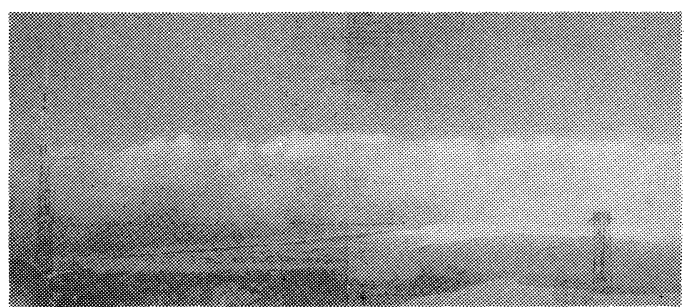

Fig. 2 Typical example of snow cloud invading to Ishikari Plain. because of a steep stable layer over the area, approximately, $2000 \sim 3000 \mathrm{~m}$ above sea level. It is significant that the cloud has a band shape with from several to $20 \mathrm{~km}$ of the width and from several tens to $100 \mathrm{~km}$ or more of the length. It is clear from routine radar photographs as shown in Fig. 3 and meteorological satellite pictures. And further, the band shape cloud has some characteristic scalloped tops with spaces of a few $\mathrm{km}$ to $10 \mathrm{~km}$ on the band. And they change to a smooth type when the cloud arrives at the seashore of Ishikari, namely, the scalloped tops became lower and diffused with some types of snowfall. Accompanied with the change of the cloud shape, the electric field on the ground shows characteristic changes likewise. Fig. 4 shows a typical example of the electric field change. In this figure, it is readily recognized that there are several patterns of the disturbances of the electric field. The disturbances are divided into four groups in magnitude to the undisturbed field, in other words, quiet and fine weather electric field which is shown in unity in the figure. The letters (L), (M), (S) and (D) in this figure indicate a large disturbance of 20 to 30 fold over undisturbed field, a medium disturbance of 10 fold, a small disturbance of a few fold and the field by the drifting snow, respectively. The polarity of the electric field except drifting snow is unsettled, but the polarity of the field of drifting snow is always negative.

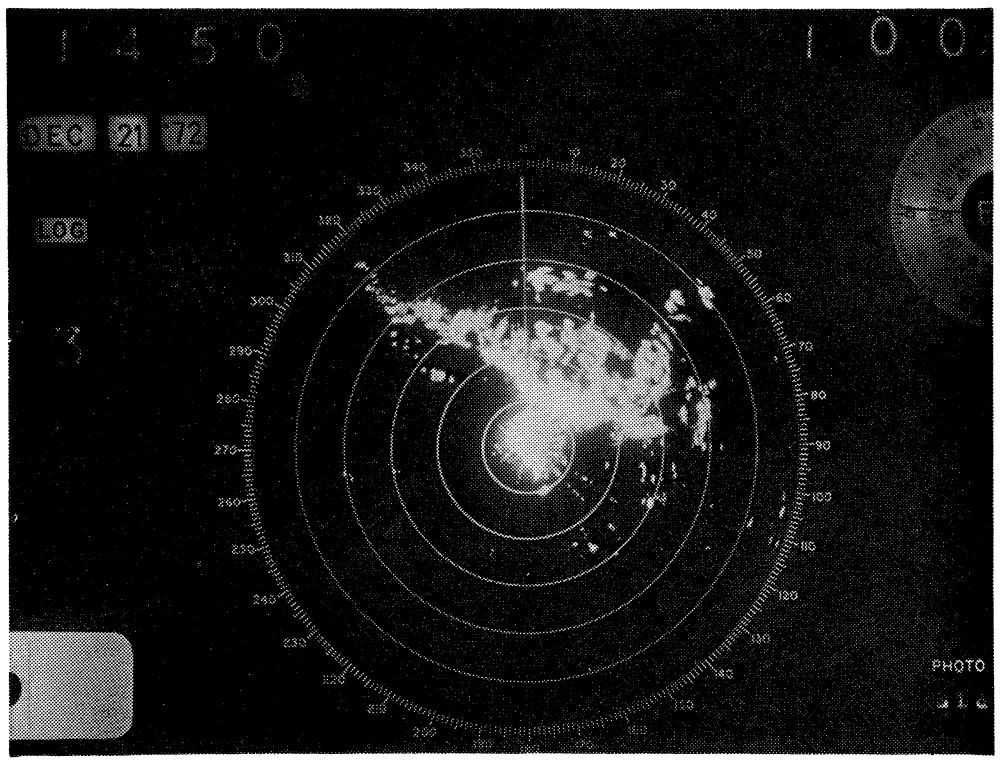

Fig. 3 Typical example of PPI radar echo of the band type snow cloud. 


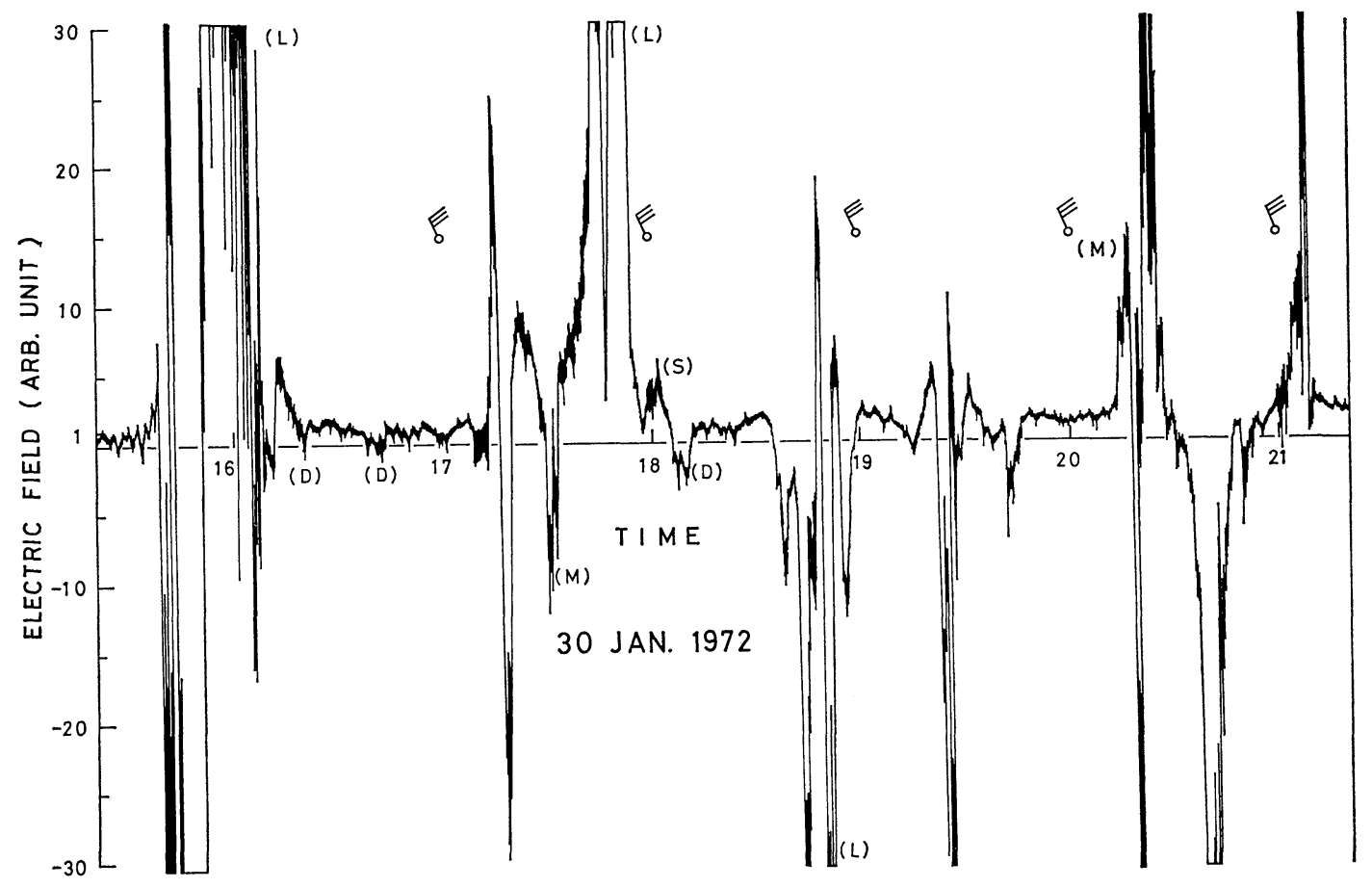

Fig. 4 Typical example of the electric field change by snowfall.

This is the same in sign in weak and medium scale of blizzard in the Antarctica (Kikuchi, 1975).

\subsection{Case of the small disturbance of the electric field}

Fig. 5 shows the case of small disturbance of the electric field, namely, a few fold of the undisturbed field. The upper part of the figure shows the time change of the electric field, and the lower the time change of the flux of the charged particles (charged particle density). The axis of the ordinate on the left side in the lower figure shows the flux of the positive and negative charged snow particles, $\left(\mathrm{N}_{+}\right)$and $\left(\mathrm{N}_{-}\right)$, per $\mathrm{cm}^{2}$. min and the right side is the average charge of the particles, $\left(\mathbf{Q}_{+}\right)$and $\left(\mathbf{Q}_{-}\right)$. The upper half shows positive polarity and lower half negative polarity. Thus the solid lines indicate the time change of the charged snow particles carrying positive and negative charges and the small dots indicate the average charges on the snow particles of which the flux of the particles is shown by solid lines. For practical purposes, although a $30 \mathrm{~cm}^{2}$ collector plate for the pre-amplifier was used, the figure of 1 on the left ordinate indicates roughly 30 snow particles per minute. In this
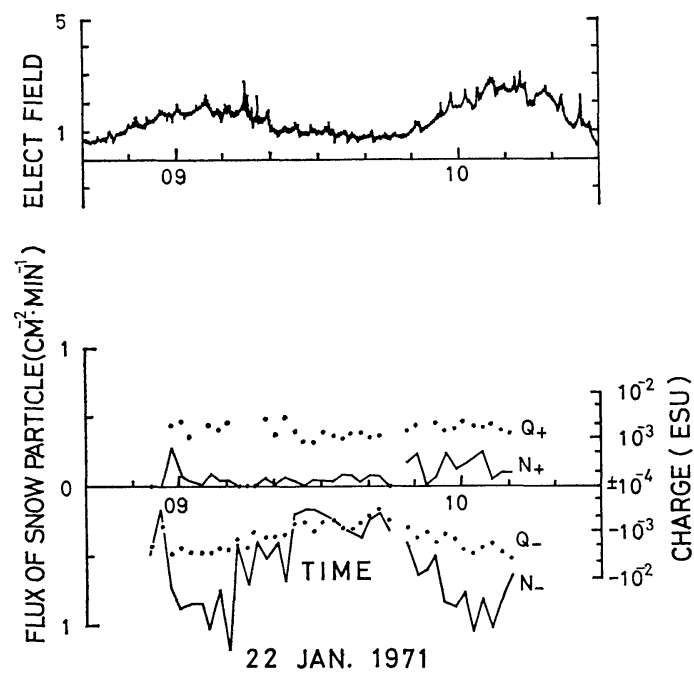

Fig. 5 Time changes of electric field (upper) and numbers, $\mathrm{N}_{+}$and $\mathrm{N}_{-}$, and average charges, $\mathrm{Q}_{+}$and $\mathrm{Q}_{-}$, of snow particles (lower).

case, the field shows positive during the period, on the other hand, the polarity of the charged particles shows overwhelmingly negative. That is to say, the mirror image relation is settled between both elements. Furthermore, it is recognized that the increasing of the field was 
accompanied by the increasing of the number of the charged particles and of the amount of the average charge of the particles. In this case, layered cloud covered widely central part of Hokkaido Island and it was recognized that cloud tops reached to $4000 \mathrm{~m}$ or more at places by PPI and RHI radar echoes. However, the disturbance of electric field was small and the amount of charges of snow crystals was small likewise. Therefore, it was found that the precipitation from layered and stratus clouds had no effect on atmospheric electrically. Sometimes, no disturbance have been recorded during relatively heavy precipitation of combination of bullets and side planes from stratus clouds.

\subsection{Case of the medium disturbance of the electric field}

One of the cases of the medium disturbance, namely approximately 10 fold over an undisturbed field shows in Fig. 6. In this case, too, it is recognized that the magnitude, large and small, of the charged particles has a good correspondence with the increase and decrease of the number of charged particles. In the same manner as described previously, it seems that the mirror image relation is formed in this case, again. Clarifying this relation, the following treatment was carried out. At first, it was formed $\left(\mathrm{N}_{+}-\mathrm{N}_{-}\right)$ at each observation time. And next, for comparison with the time change of the electric field and the time change of this $\left(\mathrm{N}_{+}-\mathrm{N}_{-}\right)$, the values of $\mp 2 \mathrm{~cm}^{-2} \cdot \mathrm{min}^{-1}$ were fixed on the scales of the electric field of $\pm 30 \mathrm{arb}$. unit (namely, the sign of particle number is inverted). The results of these treatments are shown on the same figure of the field in which they are shown by white circles connected with solid lines. The reason for the fixation of $\mp 2 \mathrm{~cm}^{-2} \cdot \mathrm{min}^{-1}$ and \pm 30 arb. unit is that in general the off-scale of the electric field in this amplification range of the sets of the equipment is recorded when the charged particles were measured 2 particles per $\mathrm{cm}^{2} \cdot \min$ or more. As shown in the figure, the curve of $\left(\mathrm{N}_{+}-\mathrm{N}_{-}\right)$shows a very good coincidence with the curve of the field. Evidently this shows the particles having the charges smaller than $1 \times 10^{-4}$ esu have no effect in the field on appearance.

\subsection{Case of the large disturbance of the electric field}

Fig. 7 shows the case of the large disturbance

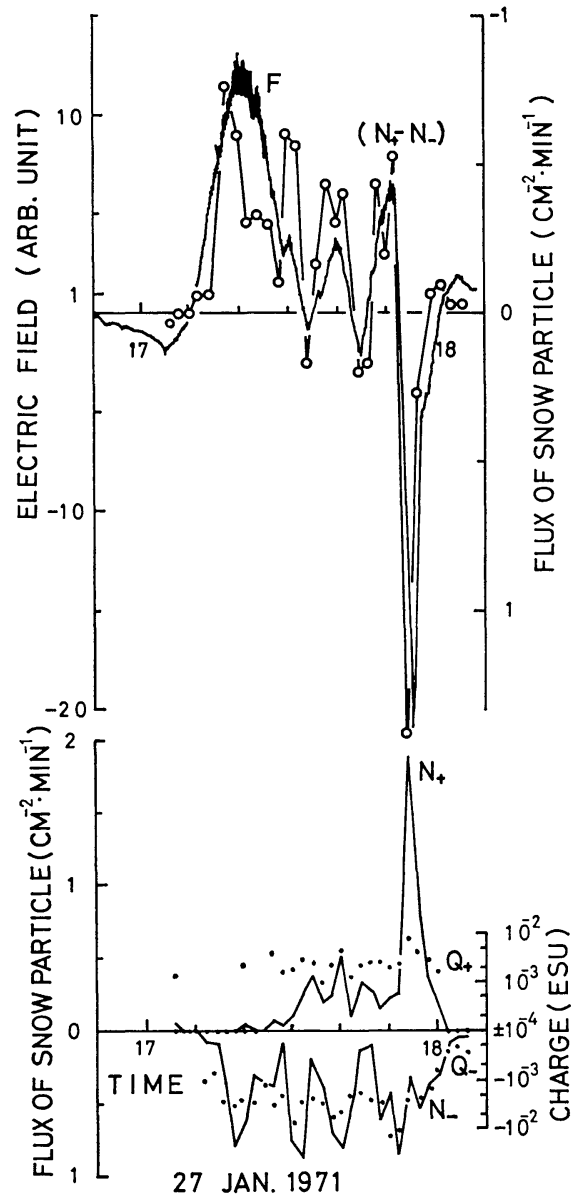

Fig. 6 Time changes of electric field and $\left(\mathrm{N}_{+}-\mathrm{N}_{-}\right)$ (upper) and numbers, $\mathrm{N}_{+}$and $\mathrm{N}_{-}$, and average charges, $Q_{+}$and $Q_{-}$, of snow particles (lower).

of the electtric field. As seen in the figure, the electric field recorded frequently an off-scale of the field (larger than 30 fold over the undisturbed one). And, simultaneously, the charged particle density exceeded 2 particles per $\mathrm{cm}^{2} \cdot \mathrm{min}^{1}$. The same treatments as described above was carried out. The result is inserted on the figure of the time change of the field by white circles connected with solid lines. Especially in this case, the time of intersection to the horizontal axis (time) of $\left(\mathrm{N}_{+}-\mathrm{N}_{-}\right)$lines shows a very good coincidence in less than a few tens seconds or one minute to that of the field. The cloud form in this case is the cumulus type and the height of the cloud top is $3500 \mathrm{~m}$ by the radar echo. 

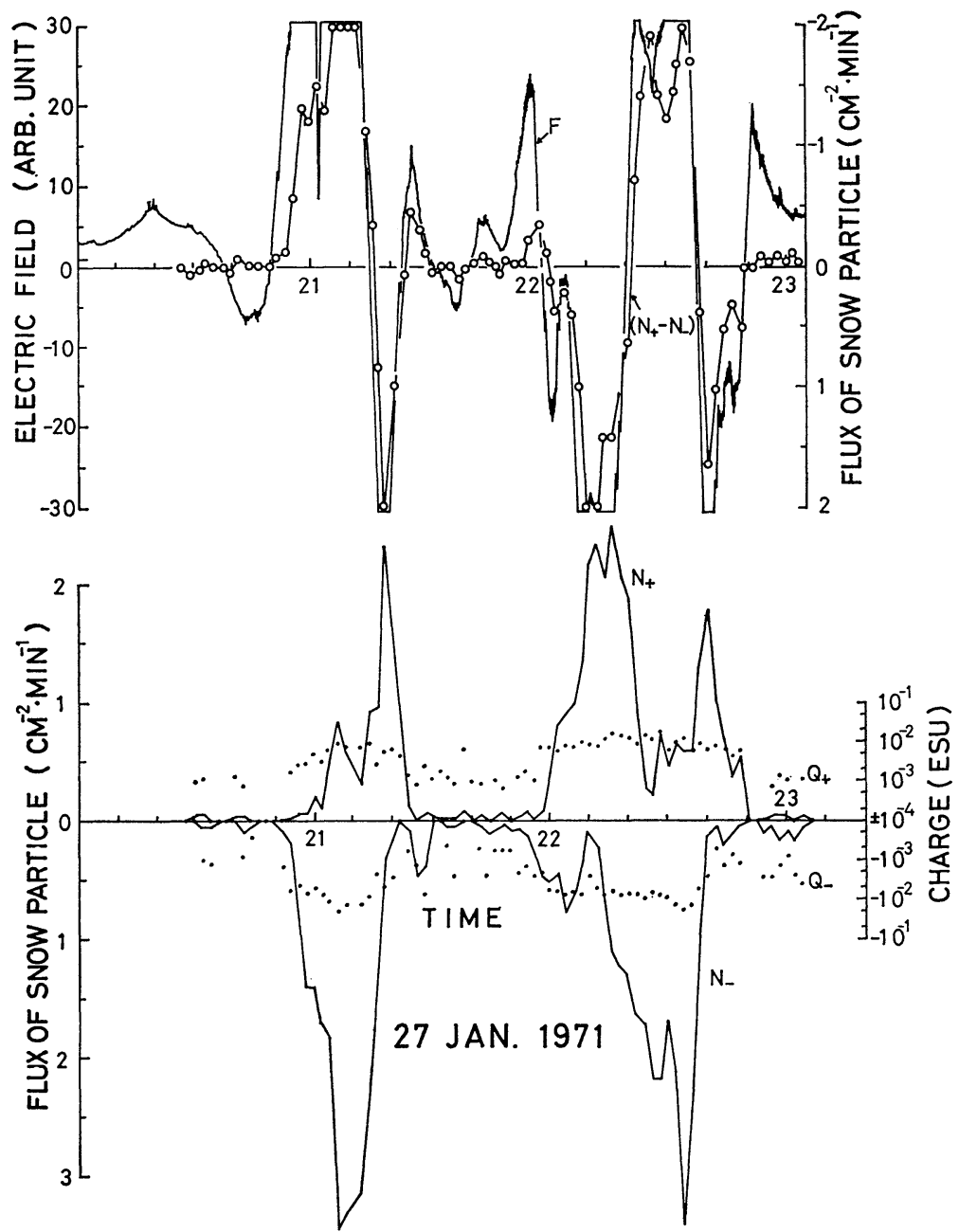

Fig. 7 Time changes of electric field and $\left(\mathrm{N}_{+}-\mathrm{N}_{-}\right)$(upper) and numbers, $\mathrm{N}_{+}$ and $\mathrm{N}_{-}$, and average charges, $\mathrm{Q}_{+}$and $\mathrm{Q}_{-}$, of snow particles (lower).

\subsection{Simultaneous observations of the electric} field, electric charges, shapes of snow crystals and melted diameter of the crystals

Fig. 8 shows the electric field in which the cycle is relatively long. And Fig. 9 shows the time change of the snow particle density, namely, $\mathrm{N}_{+}, \mathrm{N}_{-}$and $\left(\mathrm{N}_{+}-\mathrm{N}_{-}\right)$, the microscopic photographs of replicated particles and the size distributions of melted particles with the same duration of the Fig. 8. The results of the average charges of the particles are dropped in this figure because of the figure would be confused by many factors. The line of $\left(\mathrm{N}_{+}-\mathrm{N}_{-}\right)$is shown directly in the same figure and not as an inversion treated in the previous case. In this case, of course, the mirror image relation was settled between

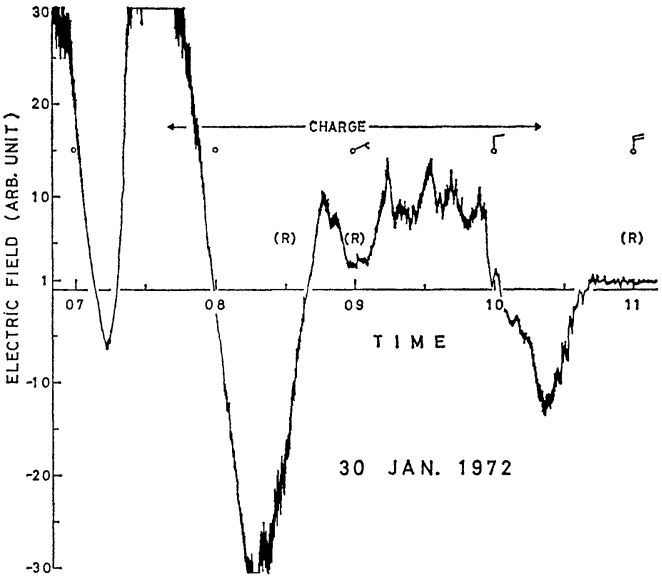

Fig. 8 Time change of electric field. 


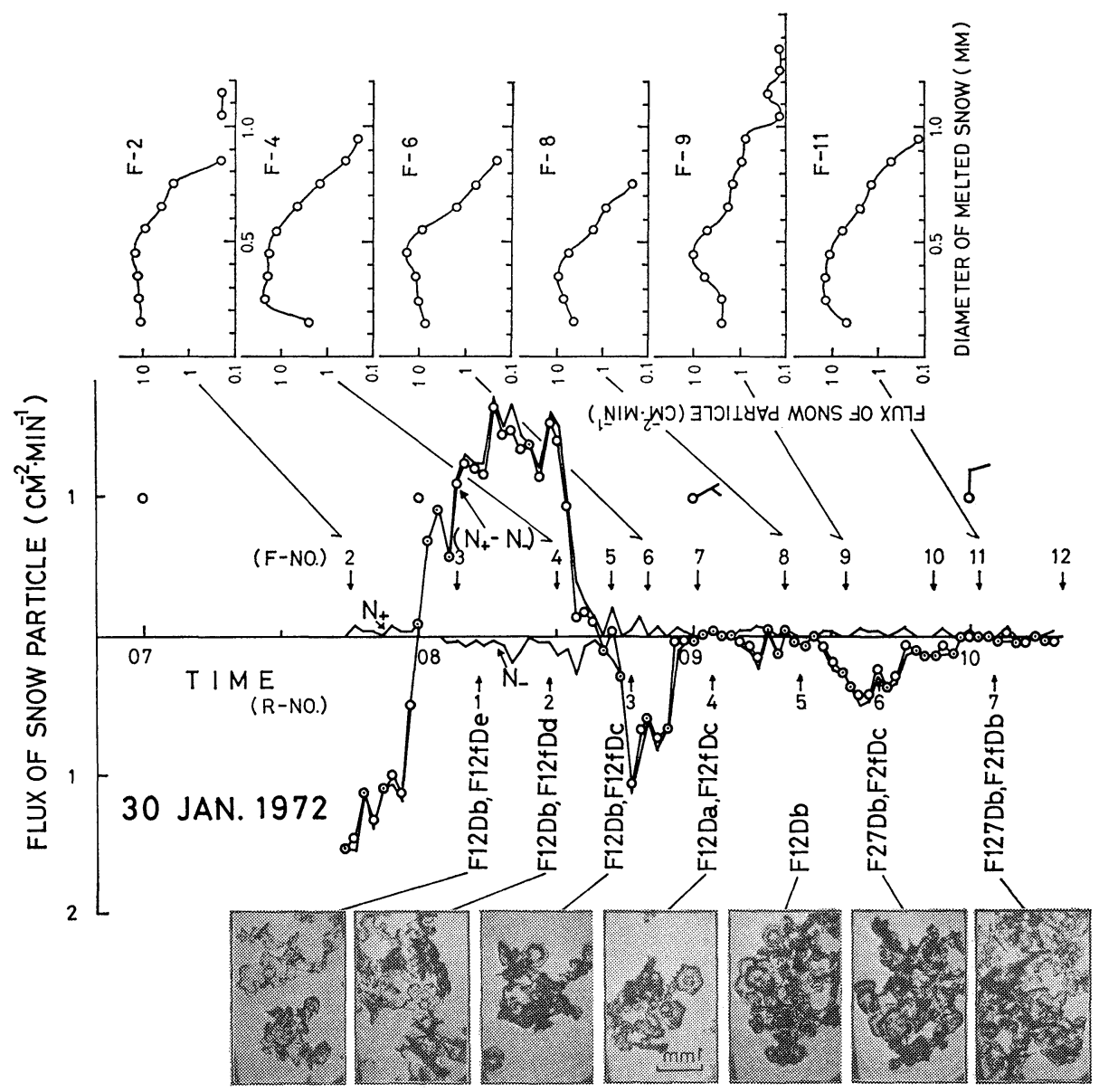

Fig. 9 Time changes of number of snow particles, $\mathrm{N}_{+}$and $\mathrm{N}_{-}$, and $\left(\mathrm{N}_{+}-\mathrm{N}_{-}\right)$, and size distributions of melted snow particles and typical examples of the shapes of snow crystals.

both elements. In this figure, (F-NO.) means the filter paper number and small downward arrows indicate the observation time by the filter paper. The size distributions of the diameters of melted snow crystals of each filter paper are shown in the upper row. Similarly, $(\mathrm{R}-\mathrm{NO}$.) means the replicated slide glass number and the small upward arrows indicate the observation time by the method. The classification of the shape of snow crystal is based upon the classification of solid precipitation by the International Commission on Snow and Ice in 1949 (Mason, $1971 \mathrm{~b})$. Capital letters of $\mathrm{F}$ and $\underline{D}$ stand for the type and size of particle, respectively. And small letters from a to $\underline{e}$ stand for the size ranges of $\underline{D}$. Further, $\underline{m}, \underline{r}, \underline{f}$ and $\underline{w}$ mean the additional characteristics of broken, rimed, flake and wet as well known. The bot- tom row shows the microscopic photographs of typical replicated snow particles of the classifica-

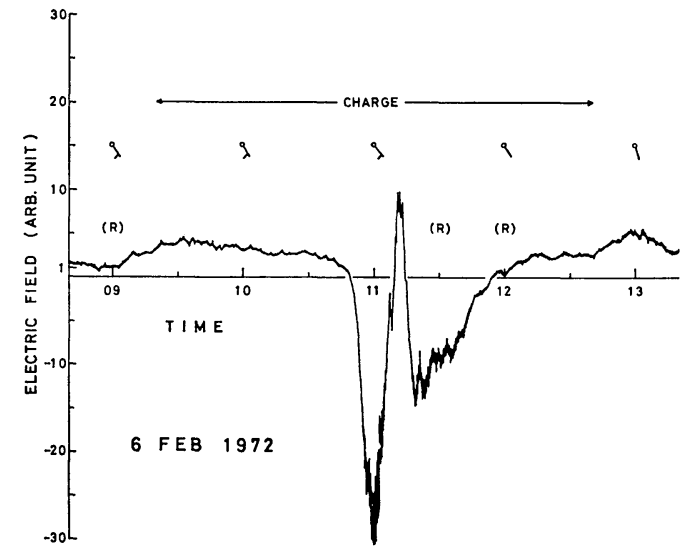

Fig. 10 Time change of electric field. 
tion connected by solid lines. In this example, especially, it is recognized that there is a distinct characteristic between the electric charge, shape and distribution of melted diameter of the snow particles. That is to say, throughout the observation period, the shapes of snow crystal were plate and stellar crystal as shown in E 1, 2. Notwith standing the fact, the charge was predominantly negative just before 0800 JST and after time, positive charges predominated till 0840 . Of course, the polarity of the field was opposite to that of the charge. And after this time, negative charges predominated but the number of crystals was smaller than the previous time. Noticeable difference of the size of the crystals was recognized before and after 0840. Namely, before the time, the sizes of the main crystals were large appearing in De and Dd, on the other hand, after the time the sizes were relatively small appearing in $\underline{\mathrm{Db}}$ and $\underline{\mathrm{Dc}}$. This tendency was clear compared

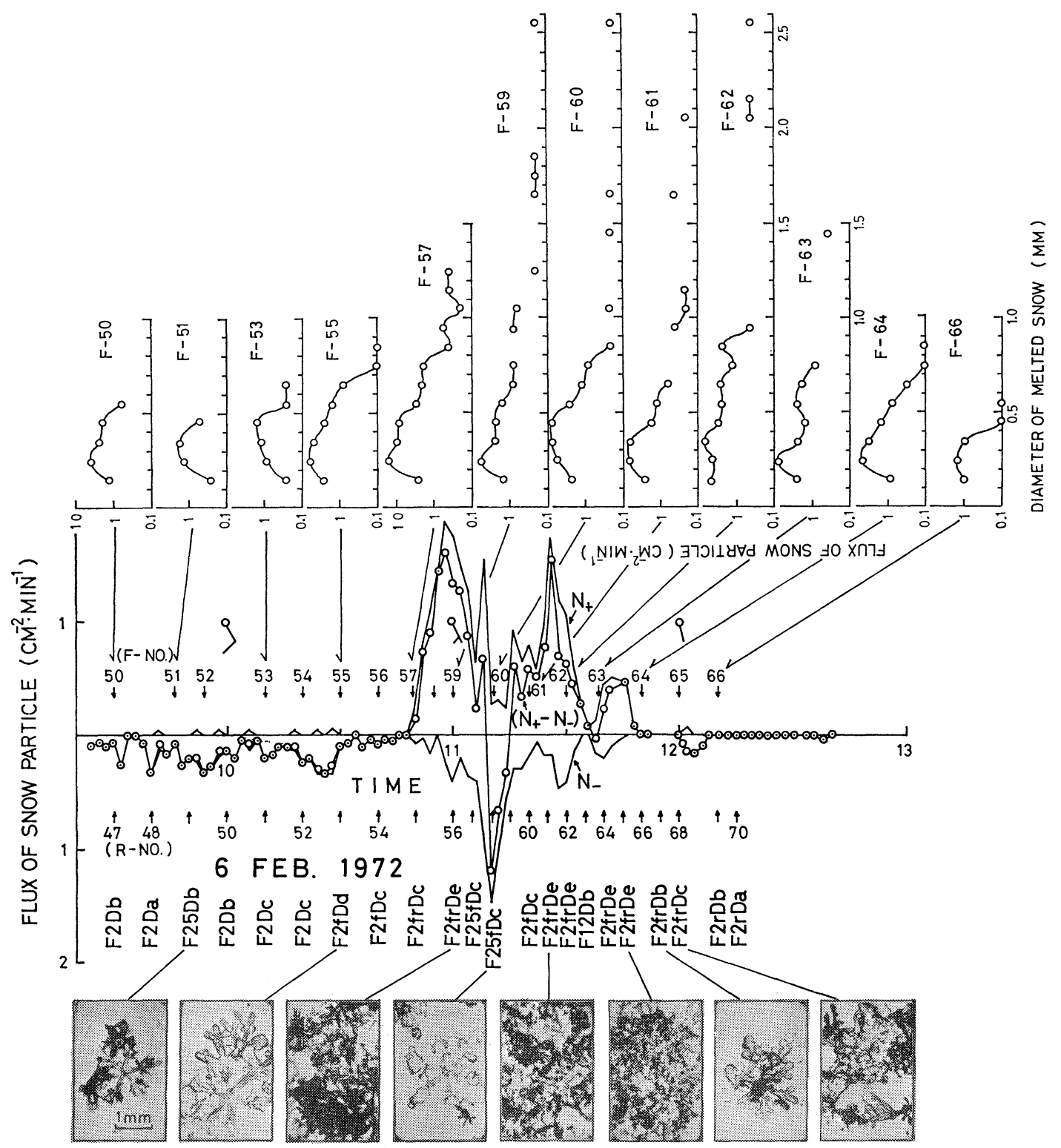

Fig. 11 Time changes of number of snow particles, $\mathrm{N}_{+}$and $\mathrm{N}_{-}$, and $\left(\mathrm{N}_{+}-\mathrm{N}_{-}\right)$, and size distributions of melted snow particles and typical examples of the shapes of snow crystals. 
with the distributions of diameter of melted snow of F-4 and 6. That is to say, in the distribution $\mathrm{F}-4$, although the main crystals were large, the maximum peak is located in smaller sized crystal. In contrast, in the distribution F-6, the maximum peak is located in larger sized crystal. Considering these facts, it indicates that there is a coexistence of the large main crystals and the small particles when the positive charge of crystal predominates. And large main crystals were measured under this measuring system. It may be considered that the charges on the small particles were not of this system.

The same example is shown in Figs. 10 and 11. As expected from the field record of Fig. 10 , fortunately, a single cell of a cumulus cloud with snowfall passed over the observation station. Thus, the field record shows a near symmetry. Comparing the field data and the result of $\left(\mathrm{N}_{+}\right.$ $-\mathrm{N}_{-}$), it is clear the mirror image relation consists of both results in less than a few tens seconds. Regarding the shapes of snow crystals, the same shape of stellar crystal, F2 was recorded during the observation period. Particularly, around 1100,1130 and $1140 \mathrm{JST}$, the crystals became snowflakes, $\underline{\mathrm{f}}$, and further rimed on the flakes, $\underline{r}$. The sizes of the crystals were larger than $4 \mathrm{~mm}$, e, and the sign of charge was predominantly positive. Around 1110 , however, the crystals were still snowflakes but the sizes were relatively smaller between 1 to $2 \mathrm{~mm}, \mathrm{c}$, and further the sign was negative. From the size distributions recorded by filter papers, the maximum peak of F-60 was at $0.5 \mathrm{~mm}$ at this time the negative charge predominated. From these examples and others, single and simple stellar and dendritic shapes of snow crystals generally show negative charges predominantly. However, it is expected that when the crystals formed relatively large snowflakes after they coalesced with each other, or when the crystals became soft hail like crystals or soft hail after they captured supercooled cloud droplets on their surfaces, the large snowflakes and soft hail obtained positive charges. Simultaneously, it was recognized that a number of small snow particles and fragments existed with the previous relatively large snow crystals as seen in the distribution curves.

\section{Consideration and conclusions}

The results obtained at the seashore of Ishikari in this paper were almost of similar tendencies qualitatively to that obtained inland $20 \mathrm{~km}$ from the shore by Magono and Orikasa (1966 a) except that the observation in the present paper was more precise and accurate compared with the above author's work, especially, in the electric field, charge and the size distribution of the melted snow particles. That is to say, it means that the snow clouds invading Sapporo are almost of a similar properties to that over the seashore electrically speaking.

Regarding the mirror image relation between the signs of electric field and of charge on snow particles in the case of quiet and light snowfalls from clouds such as the stratus type, a mechanism similar to Wilson's induction mechanism was considered between both elements (Magono and Orikasa, 1966 a). The same and almost the same mechanisms are applied to the recent thunderstorm electricity, again (Sartor, 1967; 1972; Mason, 1972). However, regarding the relation in the case of heavy snowfalls from clouds such as the cumulus type the author arrived at the conclusion that relatively large snowflakes, densely rimed crystals and soft hail were charged positively by friction with small snow particles which were charged smaller than the margin of the measurement or by disintegration of small particles or fragments from fragile snowflakes or soft hail. At this time, small fragments acquired negative charges. A negative electric field on the ground is formed by the movement of positive charged particles. The coexistence of relatively large snowflakes and densely rimed crystals, and small particles under the developing cumulus clouds was understood from the size distributions in which when the positive large crystals predominated, the mode value of the size distribution of melted diameter at the time shifted to smaller values as compared with that of when negative snow crystals predominated in a series of snowfalls. Coincidence within a few tens of seconds or one minute of the time of intersection of the record of electric field and the line of $\left(\mathrm{N}_{+}-\mathrm{N}_{-}\right)$with the zero levels of both indicates that friction and disintegration each other occur near the ground surface.

From former observations and experiments by a number of workers and this observation, a single crystal such as dendrite and plate and a snowflake which consists of a few dendritic crystals carry negative charges. On the other 
hand, the shapes of snow crystals of column, combination of bullets and side plane carry positive charges (Kikuchi, 1973). Apart from this, it is a fact that the sign of charge of the sleet and rain drops consequent on the melting of snow crystals is positive (Dinger and Gunn, 1946; Magono and Kikuchi, 1963, 1965; Kikuchi, 1965 a, b; Bent and Hutchinson, 1965; Reiter, 1969).

Furthermore, it was ascertained that relatively large snowflakes, densely rimed crystals and soft hail carry positive charges under a negative field. Therefore, it is clear that rimed crystals and soft hail carry positive charges (Isono et al., 1966; Magono and Orikasa, 1966 a). Hence, it is very important in temperate regions, the dendritic snow crystals are most frequent in snowfalls and they carry negative charges, furthermore, as they melt, coalesce and rime in their descent, they change their signs of polarity from negative to positive. There are a number of experimental results with relation to the friction and disintegration between snow crystals and snow particles and splintering when supercooled cloud droplets freeze or rime on snow crystals (Mason, $1971 \mathrm{c}$ ). However, recently Orikasa conducted experiments (1971) which gave similar results to the phenomenon observed at Ishikari described above. In his experiments carried out at Mt. Niseko, new fallen snow accumulated in metal cylinder was blown away by a blower. As a result, it was shown that small blown particles carry negative charges and large snow crystals deposited in the cylinder obtain positive charges. As described previously, therefore, the most predominant dendritic crystals in temperate regions carry negative charges under a positive field and relatively large snowflakes, densely rimed crystals and soft hail consisted of dendrite carrying positive charges by friction with small snow particles and/or by disintegration of small particles or fragments from fragile snowflakes or soft hail, and by splintering of frozen cloud droplets under a negative field. It was surmized that small particles carry away negative charges by a thermoelectric effect (Latham and Mason, 1961) or by temporary contact between both particles and crystals with different temperatures. According to Sartor (1967), charge transfer between both particles in a certain electric field occurs by collision or near collision. Therefore, if $1 \times 10^{-5}$ $\mathrm{esu} \cdot \mathrm{cm}^{-2} \cdot \mathrm{sec}^{-1}, 0.2 \mathrm{~cm},+1 \times 10^{-2}$ esu and 1000 $\mathrm{m}$ were adopted as the charging rate (Latham, 1963), the mean diameter and the amount of charge on snowflakes and the falling path of the flakes, respectively, the number of times of collision and/or near collision of $5 \times 10^{5}$ is sufficient for large crystals to become positive. Namely, 10 time $\cdot \mathrm{cm}^{-3}$, which is not especially large.

\section{Acknowledgements}

The author expresses his hearty thanks to Prof. C. Magono, Department of Geophysics, Hokkaido University, for his discussions and suggestions throughout the course of this study. The expense of this study was defrayed by the Science Fund of the Educational Ministry of Japan.

\section{References}

Bent, R.B., and W.C.A. Hutchinson, 1965: Electric space charges over melting snow on the ground. J. Atmos. Terr. Phys., 27, 91-99.

Chalmers, J.A., 1965: The relation between precipitation current and potential gradient. J. Atmos. Terr. Phys., 27, 899-905.

, 1967: Atmospheric Electricity. Pergamon Press, 515 pp. , and E.W.R. Little, 1947: Currents of atmospheric electricity. Terr. Magn. Atmos. Elect., 45, 451-462.

Dinger, J.E., and R. Gunn, 1946: Electrical effects associated with a change of state of water. Terr. Magn. Atoms. Elect., 51, 477-494.

Isono, K., M. Komabayasi, and T. Takahashi, 1966: A physical study of solid precipitation from convective clouds over the sea: Part III.-Measurement of electric charge of snow crystals-. $J$. Meteor. Soc. Japan, 44, 227-233.

Kikuchi, K., 1965 a: On the positive electrification of snow crystals in the process of their melting (III), - The relationship between air bubble concentration and charge generated in ice specimen during their melting-. J. Meteor. Soc. Japan, 43, 343350.

$1965 \mathrm{~b}$ : On the positive electrification of snow crystals in the process of their melting (IV), - Charge of droplets produced from bursting of air bubbles in ice specimen-. J. Meteor. Soc. Japan, 43, 351-358.

, 1970: Observations of the atmospheric electric field at Syowa Station, Antarctica. $J$. Meteor. Soc. Japan, 48, 452-460.

, 1973: On the polarity of the electric charges on snow crystals of the various shapes. J. Meteor. Soc. Japan, 51, 337-345.

1975: Electric charges on snow particles 
in blizzard observed at Syowa Station, Antarctica. (in preparation)

Latham, J., 1963: The electrification of frost deposits. Quart. J. Roy. Meteor. Soc., 89, 265-270.

- and B.J. Mason, 1961: Electric charge transfer associated with temperature gradients in ice. Proc. Roy. Soc., A 260, 523-536.

Magono, C., and K. Kikuchi, 1963: On the positive electrification of snow crystals in the process of their melting. J. Meteor. Soc. Japan, 41, 270277.

, and 1 1965: On the positive electrification of snow crystals in the process of their melting (II). J. Meteor. Soc. Japan, 43, 331-342.

$\longrightarrow$, K. Kikuchi, T. Kimura, S. Tazawa and T. Kasai, 1966: A study on the snowfall in the winter monsoon season in Hokkaido with special reference to low land snowfall (Investigation of natural snow crystals, VI). J. Fac. Sci., Hokkaido Univ., Ser. VII, Vol. II, 3, 287-308.

, and K. Orikasa, 1960: On the surface electric field during rainfall. J. Meteor. Soc. Japan, 38, 182-194.

, and 1961: On the surface electric field caused by the space charge of charged raindrops. J. Meteor. Soc. Japan, 39, 1-11. , and $-1966 \mathrm{a}:$ On the disturbance of surface electric field caused by snowfall. $J$. Meteor. Soc. Japan, 44, 260-279.

$\longrightarrow$, and $1966 \mathrm{~b}$ : Models of charge distribution in and under clouds during snowfall. J. Meteor. Soc. Japan, 44, 280-285.

Mason, B.J., 1971 a: The Physics of Clouds. Clarendon Press, $671 \mathrm{pp}$.

- 1971 b: The Physics of Clouds. Clarendon Press, between pp. 232-233.

- $1971 \mathrm{c}$ : The Physics of Clouds. Clarendon Press, pp. 539-557.

, 1972: The Physics of the thunderstorm.
Proc. $R$. Soc. Lond., A 327, 433-466.

Nakaya, U., and T. Terada, 1934: On the electrical nature of snow particles. J. Fac. Sci., Hokkaido Univ., Ser. II, 1, 181-190.

Orikasa, K., 1962: On the disturbance of the surface electric field caused by rain and snowfall. (in Japanese). Geophys. Bull., Hokkaido Univ., 9, 123-160.

, 1971: On the frictional electrification of new fallen snow. (in Japanese). Proc. Atmos. Elect. Japan, 5, 25-27.

Owolabi, I.E., 1970: The inverse-relation and the mirror-image effect in precipitation. J. Atmos. Terr. Phys., 32, 1205-1213.

Reiter, R., 1969: A contribution to the atmosphericelectric phenomenology of nonthunderstorm clouds and precipitations. Planetary Electrodynamics. Vol. 1, 59-83.

Sartor, J.D., 1967: The role of particle interactions in the distribution of electricity in thunderstorms. $J$. Atmos. Sci., 24, 601-615.

, 1972: Some combined electrification processes in convective clouds. Arch. Meteor. Geoph. Biokl., Ser. A, 21, 273-286.

Simpson, G.C., 1942: The electricity of cloud and rain. Quart. J. Roy. Meteor. Soc., 68, 1-34.

- 1949: Atmospheric electricity during disturbed weather. Geophys. Mem., London, 84, 1-54.

Sivaramakrishnan, M.V., 1957: Point discharge current, the earth's electric field and rain charges during disturbed weather at Poona. Indian J. Meteor. Geophys., 8, 379-390.

Takahashi, T., 1972 a: Raindrop charge-size measurements in warm rain. J. Geophys. Res., 77, 16301636 .

, 1972 b: Electric charge of cloud droplets and drizzle drops in warm clouds along the Mauna Loa-Mauna Kea Saddle Road of Hawaii Island. J. Geophys. Res., 77, 3869-3878. 


\title{
降水を伴う雪雲の大気電気的性質
}

\author{
菊 地 勝 弘 \\ （北海道大学理学部 地球物理学教室）
}

冬期北西の季節風に伴って石狩平野に進入してくる降水を伴った雪雲の大気電気的性質を知るために, 北海道石狩 町で地上大気電場, 雪結晶の結晶形とその電荷および融解直径の同時観測を行なった。

その結果, 一般にいわれているように, 単純な樹枝状六花は正電場のもとで負の電荷を持っていたが, 同じ樹枝状 六花でも比較的大きな雪片になったり, 濃密雲粒付結晶や霞になると正の電荷を持ち, 同時に電場は負になることが わかった. 更に融解直径の頻度分布の解析から, 上述の正の電荷を有する結晶が降っている時は, 最大頻度を示す直 径は, 負の電荷を有する結晶が降っている時に比べて，それより小さな值を示すことがわかった，このことから，比 較的大きな雪片や濃密雲粒付結晶が正の電荷を有する機構として, それらの結晶が降ってくる途中で外側の細かい枝 などがちぎれ，負の電荷を持ら去るためと考兄られ，また空気中に浮遊している小さな水粒が降ってくる雪片や霰と 接触するか, をたは接近した際に負の電荷を獲得し, その結果雪片や霞が正の電荷を有するものと結論された. 